\title{
Pharmacological mechanisms underlying the antinociceptive and tolerance effects of the 6,14-bridged oripavine compound 030418
}

\author{
Quan WEN, Gang YU, Yu-lei LI, Ling-di YAN*, Ze-hui GONG* \\ Department of Medicine Evaluation, Beijing Institute of Pharmacology and Toxicology, Beijing 100850, China
}

\begin{abstract}
Aim: To investigate possible pharmacological mechanisms underlying the antinociceptive effect of and tolerance to $N$-methyl-7 $\alpha$-[(R)-1hydroxy-1-methyl-3-(thien-3-yl)-propyl]-6,14-endo-ethanotetrahydronororipavine (030418), a derivative of thienorphine.

Methods: The binding affinity and efficacy of 030418 were determined using receptor binding and guanosine $5^{\prime}-0-\left(3-\left[{ }^{35} \mathrm{~S}\right]\right.$ thio)triphosphate ( $\left.\left.{ }^{35} \mathrm{~S}\right] \mathrm{GTP} \gamma \mathrm{S}\right)$ assays in $\mathrm{CHO}-\mu, \mathrm{CHO}-\mathrm{\kappa}, \mathrm{CHO}-\delta$, and $\mathrm{CHO}-\mathrm{ORL} 1$ cell membranes. The analgesic activity of and tolerance to 030418 were evaluated in thermal nociceptive tests in mice. The effects of 030418 on opioid receptors were further investigated using in vivo pharmacological antagonist blockade and in vitro tissue preparations.

Results: The compound 030418 displayed high binding affinity to all subtypes of opioid receptors with $K_{\mathrm{i}}$ values in the nanomolar range. In $\left[{ }^{35}\right.$ S $]$ GTPYS binding assay, the maximal stimulation of 030418 to $\mu-, \mathrm{K}-, \delta$-receptors and the ORL1 receptor was $89 \%, 86 \%$, $67 \%$ and $91 \%$, respectively. In hot-plate test, the antinociceptive effect of 030418 was more potent and longer than morphine. The nonselective opioid receptor antagonist naloxone could completely block 030418-induced antinociception, while both the $\mu$-opioid receptor antagonist $\beta$-FNA and the K-opioid receptor antagonist nor-BNI attenuated 030418-induced antinociception. In contrast, the ORL1 receptor antagonist J-113397 enhanced the antinociceptive effect of 030418 . Additionally, chronic treatment with 030418 resulted in a dramatic development of tolerance that could not be effectively prevented by J-113397. In guinea pig ileum preparation, the existing action of 030418 could be removed with difficulty after prolonged washing.

Conclusion: The compound 030418 is a novel agonist of opioid receptors with high efficiency, long-lasting effect and liability to tolerance, which may be closely correlated with the methyl group at the $\mathrm{N}_{17}$ position and the high hydrophobicity of the $\mathrm{C}_{7}$-thiophene group in its chemical structure.
\end{abstract}

Keywords: 030418; opioid receptor; oripavine; antinociception; drug tolerance

Acta Pharmacologica Sinica (2011) 32: 1215-1224; doi: 10.1038/aps.2011.83; published online 22 Aug 2011

\section{Introduction}

Although opioid-derived alkaloids, particularly morphine, are the standard analgesic drugs of choice in the treatment of moderate to severe pain, these compounds cause various adverse reactions ${ }^{[1,2]}$. This observation implies that developing other analgesic drugs that exhibit high potency and fewer side effects as alternatives to morphine is still a challenge that remains for pharmacologists and medicinal chemists ${ }^{[3]}$. The 6,14-bridged oripavines, which were originally derived from the Diels-Alder adducts of thebaine in the 1960s by Bentley and Hardy ${ }^{[4,5]}$, have been studied extensively to yield a rich source of resultant high-affinity opioid ligands ${ }^{[6]}$. Among

\footnotetext{
* To whom correspondence should be addressed.

E-mail yanlingdi@hotmail.com (Ling-di YAN); gongzeh@yahoo.com.cn (Ze-hui GONG)

Received 2011-03-12 Accepted 2011-05-18
}

these ligands, a number of important opioid drugs have emerged, such as etorphine/dihydroetorphine, diprenorphine, and particularly buprenorphine. In fact, buprenorphine is still used as an analgesic and is an effective alternative to methadone in the treatment of opiate dependence ${ }^{[7-10]}$.

Many compounds obtained from the structural modification of buprenorphine have also been extensively developed ${ }^{[6,11,12]}$. Inspired by these reports, $N$-cyclopropylmethyl-7a- $[(R)-1-$ hydroxy-1-methyl-3-(thien-3-yl)-propyl]-6,14-endo-ethanotetrahydronororipavine (thienorphine, Figure 1) was synthesized in our institute ${ }^{[13]}$. Previous studies have found that thienorphine has a higher potency, longer duration of action, and better oral bioavailability than buprenorphine ${ }^{[14,15]}$. Therefore, thienorphine has a pharmacological profile that indicates its use as a potential treatment for opiate abuse. However, thienorphine has been demonstrated to be a partial $\kappa$-opioid receptor agonist with low efficacy at the $\mu$-opioid receptor ${ }^{[16]}$, 


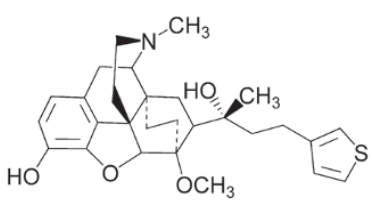

030418

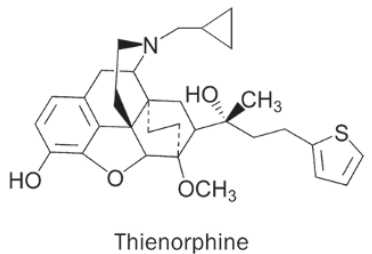

Thienorphine

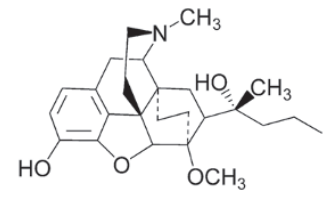

Dihydroetorphine

Figure 1. Chemical structures of the 6,14-bridged oripavine compounds 030418 , thienorphine, and dihydroetorphine.

which might cause poor compliance in addicts.

To obtain more highly efficacious compounds, a series of thienorphine derivatives that possess a thiophene group at the $C_{7}$ position have been further synthesized and assessed ${ }^{[17]}$. In primary animal experiments, one of these derivatives, $\mathrm{N}$-methyl-7a-[(R)-1-hydroxy-1-methyl-3-(thien-3-yl)-propyl]6,14-endo-ethanotetrahydronororipavine (030418, Figure 1), seemed to show powerful antinociceptive effects. In addition, 030418 exhibited a very low dependence liability in naloxone precipitated withdrawal, conditioned place preference in mice and a self-administration model in rats (unpublished data). Although 6,14-bridged oripavines that possess the complex substituents at the $\mathrm{C}_{7}$ position have been previously reported to have high binding affinities for opioid receptors ${ }^{[18,19]}$, the pharmacological mechanisms of 030418, which also belongs to the 6,14-bridged oripavine compounds, have not been studied. The present study systematically examined the binding affinity, stimulating potency, and efficacy of 030418 to the $\mu$-, $\mathrm{K}-\mathrm{\delta}$-opioid receptors and the opioid receptor-like 1 receptor (ORL1 receptor) using receptor binding and a $\left[{ }^{35} \mathrm{~S}\right] \mathrm{GTP} \gamma \mathrm{S}$ assay in Chinese hamster ovary $(\mathrm{CHO})$ cell membrane homogenates. In addition, the antinociceptive effects of and tolerance to 030418 and the gold standard morphine were comparatively evaluated in thermal stimuli-induced nociceptive tests in mice. The pharmacological properties of 030418 on opioid receptors were further investigated using in vivo pharmacological blockade of opioid receptor antagonists and in vitro guinea pig ileum preparations. These investigations illustrate the pharmacological properties and mechanisms of the antinociceptive effect of and tolerance to 030418 .

\section{Materials and methods Materials}

Compounds including 030418 hydrochloride (purity $\geq 99 \%$ ) and thienorphine hydrochloride were synthesized at our institute. Morphine hydrochloride, dihydroetorphine hydrochloride, and buprenorphine hydrochloride were purchased from Qinghai Pharmaceutical Factory (Xining, China). DAMGO, $( \pm)$ U50488, SNC80, N/OFQ, naloxone, nor-BNI, and GDP were purchased from Sigma Chemical Co (St Louis, MO, USA), while J-113397 and $\beta$-FNA were purchased from Tocris Bioscience (Bristol, UK). $\left[{ }^{3} \mathrm{H}\right]$ diprenorphine $(1.85 \mathrm{TBq} / \mathrm{mmol})$ and $\left[{ }^{35} \mathrm{~S}\right] \mathrm{GTP} \gamma \mathrm{S}(46.25 \mathrm{TBq} / \mathrm{mmol})$ were obtained from PerkinElmer Inc (Boston, MA, USA), and $\left[{ }^{3} \mathrm{H}\right]$ nociceptin/OFQ (5.70 $\mathrm{TBq} / \mathrm{mmol}$ ) was obtained from Amersham Corp (Buckinghamshire, UK). GTPץS was purchased from Biolog Life Sci- ence Institute (Bremen, Germany). $\mathrm{F}_{12}$ medium, fetal bovine serum, and G418 were obtained from Gibco (Grand Island, NY, USA) and GF/C filters from Whatman (Maidstone, UK).

\section{Animals}

Male and female Kunming mice (18-22 g, 7 weeks of age) and male Hartley guinea pigs (350-400 g, 3 months of age) were supplied by the Beijing Animal Center and maintained on a 12-h light/dark cycle (lights on between 7:00 AM and 7:00 PM). Animals were allowed access to food and water ad libitum. All experimental procedures were conducted in accordance with the Guidelines for the Use of Experimental Animals and were approved by the local ethical committee and the Institutional Review Committee on Animal Care and Use.

\section{$\mathrm{CHO}$ cell line and membrane preparation}

$\mathrm{CHO}$ cells stably expressing the rat $\mu-$, human $\mathrm{K}-$, and human $\delta$-opioid receptors and the human ORL1 receptor have previously been established in our laboratory. These cells were cultured in $\mathrm{F}_{12}$ medium supplemented with 100 units $/ \mathrm{mL}$ penicillin, $100 \mu \mathrm{g} / \mathrm{mL}$ streptomycin, $200 \mu \mathrm{g} / \mathrm{mL}$ Geneticin (G418), and $10 \%$ fetal bovine serum at $37^{\circ} \mathrm{C}$ in a humidified atmosphere consisting of $95 \%$ air and $5 \% \mathrm{CO}_{2}$. Cell membranes were prepared using a modified procedure of $\mathrm{Zhu}$ et $a l^{[20]}$. Briefly, the cells were harvested and centrifuged at $500 \times g$ for $5 \mathrm{~min}$ and the cell pellet was then suspended in Lysis buffer $(5 \mathrm{mmol} / \mathrm{L}$ Tris, $5 \mathrm{mmol} / \mathrm{L}$ EDTA, $5 \mathrm{mmol} / \mathrm{L}$ EGTA, and $0.1 \mathrm{mmol} / \mathrm{L}$ phenylmethylsulfonyl fluoride, $\mathrm{pH}$ 7.4). The cells were passed through a 29 -gauge $3 / 8$ syringe needle five times and then centrifuged. The pellet was resuspended in Tris- $\mathrm{HCl}$ buffer (50 mmol/L Tris, pH 7.4) and centrifuged again, whereupon this process was repeated. Subsequently, the membrane pellet was resuspended in Tris- $\mathrm{HCl}$ buffer $(50 \mathrm{mmol} / \mathrm{L}$ Tris, $\mathrm{pH}$ 7.4). The protein concentration was determined using the Bradford method ${ }^{[21]}$ with bovine serum albumin as the standard. All the above procedures were performed at $4{ }^{\circ} \mathrm{C}$.

\section{Receptor binding assay}

Competitive inhibition of $\left[{ }^{3} \mathrm{H}\right]$ diprenorphine $(1 \mathrm{nmol} / \mathrm{L})$ binding to the $\mu-, \mathrm{K}-$, and $\delta$-opioid receptors or $\left[{ }^{3} \mathrm{H}\right]$ nociceptin/OFQ $(0.5 \mathrm{nmol} / \mathrm{L})$ binding to the ORL1 receptor was performed in the absence or presence of various concentrations of 030418 or thienorphine. Binding was carried out in $50 \mathrm{mmol} / \mathrm{L}$ Tris- $\mathrm{HCl}$ buffer ( $\mathrm{pH} \mathrm{7.4)}$ at $37^{\circ} \mathrm{C}$ for $30 \mathrm{~min}$ in duplicate in a final volume of $0.5 \mathrm{~mL}$ with $20-40 \mu \mathrm{g}$ of membrane protein. 
Naloxone $(5 \mu \mathrm{mol} / \mathrm{L})$ and N/OFQ $(5 \mu \mathrm{mol} / \mathrm{L})$ were used to define nonspecific binding. Subsequently, bound and free $\left[{ }^{3} \mathrm{H}\right]$ diprenorphine or $\left[{ }^{3} \mathrm{H}\right]$ nociceptin/OFQ were separated by filtration under reduced pressure with GF/C filters presoaked with $0.2 \%$ polyethyleneimine. The radioactivity on the filters was determined by liquid scintillation counting (LS6500, Beckmen Inc, USA). Each experiment was performed in duplicate and repeated at least three times. The competitive binding data were fitted to sigmoidal curves for the determination of $\mathrm{IC}_{50}$ values. The $K_{\mathrm{i}}$ values of each drug were derived from the $\mathrm{IC}_{50}$ values using the following equation: $K_{\mathrm{i}}=\mathrm{IC}_{50} /\left[1+\left[{ }^{3} \mathrm{H}\right]\right.$ ligand $/ K_{d}$. Based on our previous experiments, the $K_{d}$ values of $\left[{ }^{3} \mathrm{H}\right]$ diprenorphine to the $\mu-, \mathrm{K}-$, and $\delta$-opioid receptors and $\left[{ }^{3} \mathrm{H}\right]$ nociceptin/OFQ to the ORL1 receptor were $0.56 \mathrm{nmol} / \mathrm{L}$, $0.55 \mathrm{nmol} / \mathrm{L}, 0.46 \mathrm{nmol} / \mathrm{L}$, and $0.29 \mathrm{nmol} / \mathrm{L}$, respectively.

\section{$\left[{ }^{35} \mathrm{~S}\right] \mathrm{GTP}$ S binding assay}

Membrane protein $(15-50 \mu \mathrm{g})$ was incubated with different concentrations of 030418 , thienorphine, or dihydroetorphine $\left(10^{-13}\right.$ to $\left.10^{-5} \mathrm{~mol} / \mathrm{L}\right)$ in buffer A (100 mmol/L Tris, $100 \mathrm{mmol} / \mathrm{L}$ $\mathrm{NaCl}$, and $5 \mathrm{mmol} / \mathrm{L} \mathrm{MgCl}_{2}$, pH 7.4) containing $\left.{ }^{35} \mathrm{~S}\right] \mathrm{GTP} \gamma \mathrm{S}$ $(200 \mathrm{pmol} / \mathrm{L})$ and GDP $(20-40 \mu \mathrm{mol} / \mathrm{L})$ in a total volume of $0.5 \mathrm{~mL}$ at $30^{\circ} \mathrm{C}$ for $60 \mathrm{~min}$. Nonspecific binding was defined by incubation in the presence of $20 \mu \mathrm{mol} / \mathrm{L}$ GTP $\gamma$ S. Bound and free $\left.{ }^{35} \mathrm{~S}\right] \mathrm{GTP} \gamma \mathrm{S}$ was separated by filtration with GF/C filters under reduced pressure and rinsed three times with icecold buffer B ( $50 \mathrm{mmol} / \mathrm{L}$ Tris- $\mathrm{HCl}, 50 \mathrm{mmol} / \mathrm{L} \mathrm{NaCl}$, and 5 $\mathrm{mmol} / \mathrm{L} \mathrm{MgCl}_{2}, \mathrm{pH}$ 7.4). The radioactivity on the filters was determined by liquid scintillation counting. The maximal stimulation of each of the selective agonists DAMGO $(\mu)$,

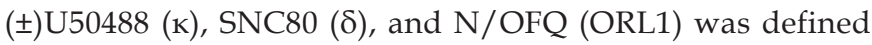
as the $100 \%$ effect in this experiment. Each experiment was performed in duplicate and repeated at least three times. The concentration-response data were fitted to sigmoidal curves for the determination of $\mathrm{EC}_{50}$ values and the maximal effects $\left(E_{\max }\right)$.

\section{Tail-flick test}

The mouse tail-flick test was adapted for measuring the latency of the tail-flick response ${ }^{[22]}$. Mice were gently held by hand with their tail positioned in an apparatus (Tail-flick Analgesia Meter, Columbia instruments, OH, USA) for radiant heat stimulation on the surface of the tail. The intensity of the heat stimulus was adjusted so that the animal flicked its tail after 3 to $5 \mathrm{~s}$ for a baseline reading. The inhibition of the tail-flick response was expressed as a percentage of maximal possible effect (\%MPE), which was calculated as \%MPE $=\left[\left(T_{1}-\right.\right.$ $\left.\left.T_{0}\right) /\left(T_{2}-T_{0}\right)\right] \times 100 \%$, where $T_{0}$ and $T_{1}$ were the tail-flick latencies before and after the treatments, respectively, and $T_{2}$ was the cut-off time, which was set at $10 \mathrm{~s}$ to avoid injury of the tail.

\section{Hot-plate test}

The mouse hot-plate test, as previously reported ${ }^{[23]}$, was used to assess the antinociceptive effects of the compounds. Female mice were individually placed on the surface of a hot plate (Hugo Sachs Elektronik-Harvard Apparatus GmbH, March-
Hugstetten, Germany) maintained at $55 \pm 0.5^{\circ} \mathrm{C}$. The latency time for hind-paw licking was recorded as the nociceptive response. Mice with a baseline latency shorter than $5 \mathrm{~s}$ or longer than $30 \mathrm{~s}$ were eliminated. The antinociceptive data are also presented as \% MPE calculated using the equation $\% \mathrm{MPE}=\left[\left(T_{1}-T_{0}\right) /\left(T_{2}-T_{0}\right)\right] \times 100 \%$, where $T_{0}$ and $T_{1}$ were the latency times of hind-paw licking before and after treatment, respectively, and $T_{2}$ was the cutoff time, which was set at $60 \mathrm{~s}$ to avoid injury of the animal's paw.

\section{Dosage regimen and injection procedure in thermal nociception}

To establish the dose-response curves in acute thermal nociception tests, mice ( $n=8-10$ per group) received sc injections of 030418 alone $(1.6-4.0 \mu \mathrm{g} / \mathrm{kg}$ for the tail-flick and $1.4-5.7 \mu \mathrm{g} / \mathrm{kg}$ for the hot-plate test). To compare the effects of 030418 with those of other opioid drugs, morphine $(0.7-9.9 \mathrm{mg} / \mathrm{kg}$ sc for tail-flick and $1.3-10.0 \mathrm{mg} / \mathrm{kg}$ sc for hot-plate) and dihydroetorphine $(0.25-0.9 \mu \mathrm{g} / \mathrm{kg}$ sc for tail-flick and 1.3-2.9 $\mu \mathrm{g} / \mathrm{kg}$ sc for hot-plate) dose-response curves for thermal antinociception were determined using parameters similar to those described above. The animals were tested for response latency $30 \mathrm{~min}$ after administration of 030418, morphine, or dihydroetorphine.

To determine the duration of antinociceptive action during the hot-plate test, mice were administered $030418(6.0 \mu \mathrm{g} / \mathrm{kg}$, $\mathrm{sc})$, dihydroetorphine $(3.0 \mu \mathrm{g} / \mathrm{kg}, \mathrm{sc})$, or morphine $(10 \mathrm{mg} / \mathrm{kg}$, sc) and tested at $0.5,1,1.5,2,3,4,6,8,10$, and $12 \mathrm{~h}$ after injection. The doses of 030418 , dihydroetorphine, and morphine were chosen because they produced the greatest level of antinociception of the doses tested.

To determine the effects of different opioid receptor antagonists on the analgesic effects produced by 030418 during the hot-plate test, the animals were pretreated with the nonselective opioid antagonist naloxone $(1 \mathrm{mg} / \mathrm{kg}$, sc), the $\mu$-opioid receptor antagonist $\beta$-FNA $(10 \mu \mathrm{g} /$ mouse, icv), and the $\mathrm{K}$-opioid receptor antagonist nor-BNI $(3.7 \mu \mathrm{g} /$ mouse, icv) before sc injection of $030418(4.0 \mu \mathrm{g} / \mathrm{kg}$, approximate $\mathrm{ED}_{80}$ ). Animals were also pretreated with the ORL1 receptor antagonist J-113397 (4.0 $\mathrm{gg} /$ mouse, icv) before sc injection of $030418\left(2.0 \mu \mathrm{g} / \mathrm{kg}\right.$, approximate $\left.\mathrm{ED}_{60}\right)$. In the experiments, the opioid receptor antagonists naloxone, $\beta$-FNA, nor-BNI, and J-113397 were respectively administered $15 \mathrm{~min}, 24 \mathrm{~h}$, $24 \mathrm{~h}$, and $15 \mathrm{~min}$ prior to the agonists. The dosage and time intervals of these antagonists were based on previous experiments and reports ${ }^{[24-26]}$. The doses of the other opioid agonists were administered as follows: morphine $(6.0 \mathrm{mg} / \mathrm{kg}, \mathrm{sc})$, DAMGO (50 ng/mouse, icv), ( \pm )U50488 (50 $\mu \mathrm{g} /$ mouse, icv), and buprenorphine $(1.7 \mathrm{mg} / \mathrm{kg}$, sc). Animals were tested for response latency $15 \mathrm{~min}$ after icv injection of DAMGO and ( \pm U50488 or $30 \mathrm{~min}$ after sc injection of 030418, morphine, and buprenorphine. The control groups were given a corresponding volume of vehicle injection.

To establish a chronic analgesic tolerance model during the hot-plate test, animals received sc injections of high doses of $030418(18.0 \mu \mathrm{g} / \mathrm{kg}$, once daily), morphine $(30.0 \mathrm{mg} / \mathrm{kg}$, thrice daily), or vehicle for 7 consecutive days. The dosage regimen 
was used for the induction of drug tolerance, as previously reported by our laboratory ${ }^{[27]}$. The antinociceptive effects were measured $30 \mathrm{~min}$ after administration of the opioid drugs every day to monitor the development of tolerance. In this chronic tolerance model, mice were pretreated with the ORL1 receptor antagonist J-113397 (4.0 $\mu \mathrm{g} /$ mouse, icv) or vehicle 15 min before the last injection of morphine or 030418 on $\mathrm{d} 7$, and the animals were tested at different times after the administration of morphine $(30.0 \mathrm{mg} / \mathrm{kg}$, sc) or $030418(18.0 \mu \mathrm{g} / \mathrm{kg}$, sc) on $\mathrm{d} 1$ and $\mathrm{d} 7$, respectively.

\section{Isolated tissue bioassay}

The longitudinal muscle of guinea pigs was gently separated from the underlying circular muscle of the ileum using the method described by Paton and Vizi ${ }^{[28]}$ and placed under $1 \mathrm{~g}$ tension in a $5 \mathrm{~mL}$ organ bath containing Krebs-Henseleit solution $(118 \mathrm{mmol} / \mathrm{L} \mathrm{NaCl}, 4.7 \mathrm{mmol} / \mathrm{L} \mathrm{KCl}, 2.5 \mathrm{mmol} / \mathrm{L}$ $\mathrm{CaCl}_{2}, 1.2 \mathrm{mmol} / \mathrm{L} \mathrm{MgSO}_{4}, 1.2 \mathrm{mmol} / \mathrm{L} \mathrm{KH}_{2} \mathrm{PO}_{4}, 25 \mathrm{mmol} / \mathrm{L}$ $\mathrm{NaHCO}_{3}$, and $10 \mathrm{mmol} / \mathrm{L}$ glucose). The bath was maintained at $37{ }^{\circ} \mathrm{C}$ and continuously bubbled with a mixture of $95 \% \mathrm{O}_{2}$ and $5 \% \mathrm{CO}_{2}$. Muscle contractions were recorded using an isometric transducer coupled to a multichannel polygraph. The data acquired from the samples stimulated by acetylcholine chloride $(1.0 \mu \mathrm{mol} / \mathrm{L})$ was recorded as the ileum muscle contraction response. A single 030418 (0.1 mmol/L), morphine (5 mmol/L), dihydroetorphine $(0.2 \mathrm{mmol} / \mathrm{L})$, or vehicle was added to the organ bath containing the tissue preparations ( $n=3-4$ samples per group). The response of ileum muscle contractions to opioid drugs was expressed as \%inhibition, which was calculated as \%inhibition=[1-(muscle contractions after treatment)/(muscle contractions before treatment)] $\times 100 \%$. The tissue preparations were measured at different times during prolonged washing, and the time-course curves were generated.

\section{Statistical analysis}

All the data in this study are expressed as mean \pm SEM. The $\mathrm{ED}_{50}$ values with $95 \%$ confidence limits in the antinociceptive assays were calculated using the method described by Bliss ${ }^{[29]}$. The competition binding data and concentration-response data in $\left[{ }^{35} \mathrm{~S}\right] \mathrm{GTP} \gamma \mathrm{S}$ assays were fitted by nonlinear regression analysis using the Origin 6.0 program (Northampton, MA, USA). The effects of the opioid receptor agonists and antagonists in the hot-plate tests were analyzed using one-way ANOVA followed by the SNK test. The time-course of the drug effects was analyzed using two-way ANOVA for repeated measures followed by Bonferroni-corrected Student's $t$ test. All statistical analyses were performed using SPSS 13.0 (SPSS Inc, Chicago, IL, USA), and $P<0.05$ was the level of statistical significance.

\section{Results}

Binding affinity of 030418 to opioid receptors and the ORL1 receptor

As shown in Table 1, 030418 showed high binding affinities to all four subtypes of opioid receptors with $K_{\mathrm{i}}$ values for inhibit-
Table 1. Apparent $K_{\mathrm{i}}$ values (nmol/L) of 030418 and thienorphine for $\mu$-, $\mathrm{K}$-, $\delta$-opioid receptors and the ORL1 receptor. Competitive inhibition of $\left[{ }^{3} \mathrm{H}\right]$ diprenorphine or $\left[{ }^{3} \mathrm{H}\right]$ nociceptin/OFQ by 030418 and thienorphine was performed in membranes from $\mathrm{CHO}-\mu, \mathrm{CHO}-\kappa, \mathrm{CHO}-\delta$, and $\mathrm{CHO}-\mathrm{ORL} 1$ cells as described in Materials and methods. Each value represents mean \pm SEM from at least three independent experiments performed in duplicate.

\begin{tabular}{lcccr}
\hline \multirow{2}{*}{ Compound } & \multicolumn{4}{c}{$K_{\mathrm{i}}(\mathrm{nmol} / \mathrm{L})$} \\
& $\mu$ & $\kappa^{2}$ & $\delta$ & \multicolumn{1}{c}{ ORL1 } \\
\hline 030418 & $0.91 \pm 0.05$ & $0.60 \pm 0.28$ & $0.58 \pm 0.21$ & $1.6 \pm 0.4$ \\
Thienorphine & $1.4 \pm 0.1$ & $0.34 \pm 0.15$ & $0.63 \pm 0.48$ & $36.5 \pm 3.0$ \\
\hline
\end{tabular}

ing $\left[{ }^{3} \mathrm{H}\right]$ diprenorphine or $\left[{ }^{3} \mathrm{H}\right]$ nociceptin/OFQ binding in the nanomolar range. The ratio of the $K_{i}$ values was 1:0.7:0.6:1.7 for $\mu: \kappa: \delta: O R L 1$. Similarly, thienorphine also exhibited no selectivity for all four subtypes of receptors. Nevertheless, the $K_{\mathrm{i}}$ value for the inhibition of $\left[{ }^{3} \mathrm{H}\right]$ nociceptin/OFQ binding to the ORL1 receptor by thienorphine was approximately 22-fold higher than that of 030418.

Potency and efficacy of 030418 in the $\left[{ }^{35} \mathrm{~S}\right] \mathrm{GTPYS}$ binding assay As controls for each receptor, the subtype selective, highly

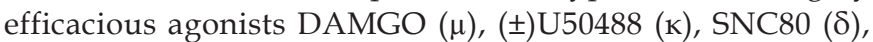
and N/OFQ (ORL1) increased the binding of $\left[{ }^{35} S\right] G T P \gamma S$ in a concentration-dependent manner and produced maximal stimulations of $174 \%, 204 \%, 162 \%$, and $287 \%$ over the basal level, respectively. The $\mathrm{EC}_{50}$ values and maximal effects $\left(E_{\max }\right)$ are shown in Figure 2 and Table 2. The compound 030418 produced a maximal stimulation of $89 \%$ on the $\mu$-opioid receptor, $86 \%$ on the $\mathrm{K}$-opioid receptor, $67 \%$ on the $\delta$-opioid receptor, and $91 \%$ on the ORL1 receptor. The $\mathrm{EC}_{50}$ values of 030418 for the $\mu-, \kappa_{-}$, and $\delta$-opioid receptors and the ORL1 receptor were $0.10,0.15,0.38$, and $15 \mathrm{nmol} / \mathrm{L}$, respectively. Comparatively, thienorphine only partially activated the $\mu$ - and $\mathrm{k}$ - receptors and showed a maximal response of $28 \%$ and $65 \%$, respectively. The $\mathrm{EC}_{50}$ values for thienorphine were in the nanomolar range, but this compound was inactive at the $\delta$-opioid receptor and the ORL1 receptor. In addition, dihydroetorphine exhibited full agonism at the $\mu-, \kappa_{-}$, and $\delta$-opioid receptors and moderate, low-potency agonism at the ORL1 receptor.

\section{Antinociceptive effect of 030418}

According to the data shown in Figure 3, 030418 presented full opioid agonist characteristics with typical sigmoid doseresponse curves in thermal stimuli-induced nociceptive models. In the mouse tail-flick test and hot-plate test, the antinociceptive $\mathrm{ED}_{50}(95 \%$ confidence limits) values of 030418 were calculated to be $2.39 \mu \mathrm{g} / \mathrm{kg}$ sc $(2.26-2.52)$ and $2.90 \mu \mathrm{g} / \mathrm{kg} \mathrm{sc}$ (2.42-3.37), respectively. In comparison, the $\mathrm{ED}_{50}(95 \%$ confidence limits) values of the gold standard morphine were 3.74 $\mathrm{mg} / \mathrm{kg} \mathrm{sc}(2.42-5.05)$ and $3.20 \mathrm{mg} / \mathrm{kg} \mathrm{sc}$ (3.02-3.39), respectively. The $\mathrm{ED}_{50}(95 \%$ confidence limits) values of another pure full agonist, dihydroetorphine, were $0.66 \mu \mathrm{g} / \mathrm{kg}$ sc (0.61-0.72) 

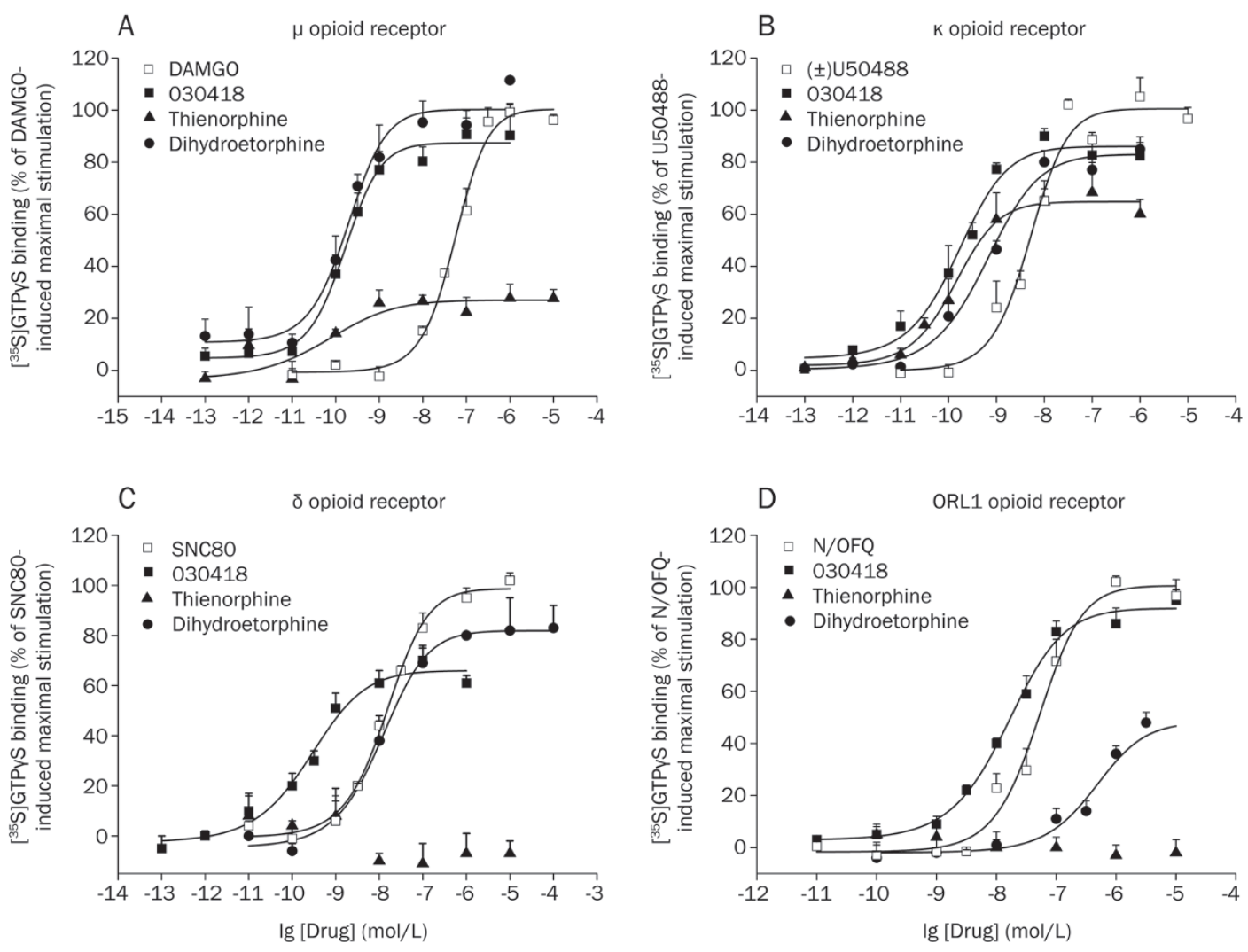

Figure 2. Stimulation of $\left[{ }^{35} \mathrm{~S}\right] \mathrm{GTPYS}$ binding to membranes of $\mathrm{CHO}-\mu(\mathrm{A}), \mathrm{CHO}-\mathrm{K}(\mathrm{B}), \mathrm{CHO}-\delta(\mathrm{C})$, and CHO-ORL1 (D) cells by 030418, thienorphine, dihydroetorphine, and a selective full agonist for each subtype of opioid receptors. $\left[{ }^{35} \mathrm{~S}\right] \mathrm{GTPYS}$ binding was performed as described in the Materials and methods. $\left.{ }^{35} \mathrm{~S}\right] \mathrm{GTPYS}$ binding data were normalized to the percentage of maximal efficacy induced by each selective full agonist. Each value represents the mean \pm SEM from at least three independent experiments performed in duplicate. The $\mathrm{EC}_{50}$ values and maximal effects $\left(E_{\max }\right)$ are shown in Table 2.

Table 2. $\mathrm{EC}_{50}$ values $(\mathrm{nmol} / \mathrm{L})$ and $E_{\max }(\%)$ of 030418 , thienorphine, and dihydroetorphine in stimulating $\left[{ }^{35} \mathrm{~S}\right] \mathrm{GTPYS}$ binding to membranes of $\mathrm{CHO}-\mu-$, $\mathrm{CHO}-\kappa, \mathrm{CHO}-\delta$, and CHO-ORL1 cells. Maximal stimulation of binding was defined using the selective agonists DAMGO $(\mu),( \pm)$ U50488 $(\kappa)$, SNC80 ( $\delta)$, and N/OFQ (ORL1). Data were derived from the curves in Figure 2. Each value represents mean \pm SEM from at least three independent experiments performed in duplicate.

\begin{tabular}{|c|c|c|c|c|c|c|c|c|}
\hline \multirow[b]{2}{*}{ Compound } & \multicolumn{2}{|c|}{$\mu$} & \multicolumn{2}{|c|}{ k } & \multicolumn{2}{|c|}{$\delta$} & \multicolumn{2}{|c|}{ ORL1 } \\
\hline & $\begin{array}{c}\mathrm{EC}_{50} \\
(\mathrm{nmol} / \mathrm{L})\end{array}$ & $\begin{array}{l}E_{\max } \\
(\%)\end{array}$ & $\begin{array}{c}\mathrm{EC}_{50} \\
(\mathrm{nmol} / \mathrm{L})\end{array}$ & $\begin{array}{l}E_{\max } \\
(\%)\end{array}$ & $\begin{array}{c}\mathrm{EC}_{50} \\
(\mathrm{nmol} / \mathrm{L})\end{array}$ & $\begin{array}{l}E_{\max } \\
(\%)\end{array}$ & $\begin{array}{c}\mathrm{EC}_{50} \\
(\mathrm{nmol} / \mathrm{L})\end{array}$ & $\begin{array}{l}E_{\max } \\
(\%)\end{array}$ \\
\hline DAMGO & $65.8 \pm 13.7$ & 100 & & & & & & \\
\hline$( \pm) \cup 50488$ & & & $4.8 \pm 1.0$ & 100 & & & & \\
\hline SNC80 & & & & & $13.2 \pm 2.2$ & 100 & & \\
\hline Thienorphine & $0.07 \pm 0.03$ & $28 \pm 4$ & $0.13 \pm 0.03$ & $65 \pm 8$ & & & & \\
\hline Dihydroetorphine & $0.18 \pm 0.04$ & $98 \pm 9$ & $0.60 \pm 0.15$ & $83 \pm 4$ & $7.7 \pm 1.9$ & $81 \pm 6$ & $457 \pm 110$ & $50 \pm 4$ \\
\hline
\end{tabular}

NS, no stimulation up to $10 \mu \mathrm{mol} / \mathrm{L}$.

and $1.71 \mu \mathrm{g} / \mathrm{kg}$ sc (1.62-1.80), respectively. As shown in Figure 4 , the maximally effective dose of $030418(6.0 \mu \mathrm{g} / \mathrm{kg}, \mathrm{sc})$ had the longest duration of the antinociceptive effect in the mouse hot-plate test compared to that of dihydroetorphine $(3.0 \mu \mathrm{g} / \mathrm{kg}$, sc) and morphine $(10.0 \mathrm{mg} / \mathrm{kg}, \mathrm{sc})$. This dose of 030418 maintained the maximal antinociceptive activity for at least $2 \mathrm{~h}$ after administration and was ineffective $10 \mathrm{~h}$ after administration.

\section{Effects of opioid receptor antagonists on antinociception of 030418}

In the mouse hot-plate test, $030418(4.0 \mu \mathrm{g} / \mathrm{kg}$, sc), morphine 

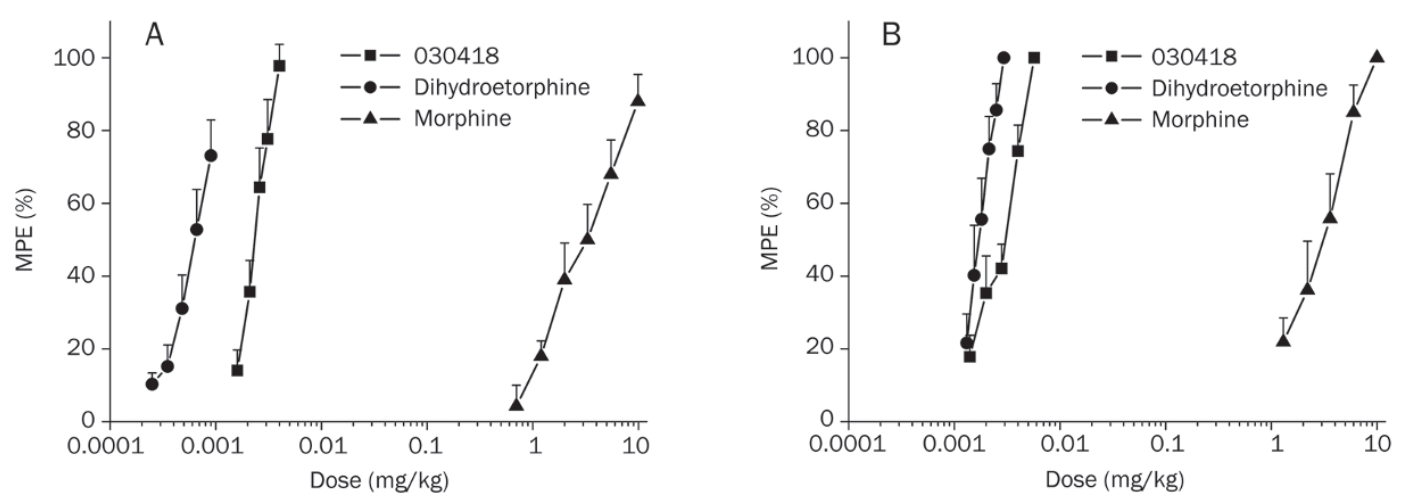

Figure 3. Dose-response curves of the antinociceptive effects produced by sc administration of 030418 , dihydroetorphine, and morphine in mice. (A) Antinociceptive effects of $030418(1.6-4.0 \mu \mathrm{g} / \mathrm{kg}, \mathrm{sc})$, dihydroetorphine $(0.25-0.9 \mu \mathrm{g} / \mathrm{kg}, \mathrm{sc})$, and morphine $(0.7-9.9 \mathrm{mg} / \mathrm{kg}$, sc) in the tail-flick test; (B) Antinociceptive effects of $030418(1.4-5.7 \mu \mathrm{g} / \mathrm{kg}, \mathrm{sc})$, dihydroetorphine $(1.3-2.9 \mu \mathrm{g} / \mathrm{kg}, \mathrm{sc})$, and morphine $(1.3-10.0 \mathrm{mg} / \mathrm{kg}, \mathrm{sc})$ in the hot-plate test. The data are expressed as \%MPE, and each point represents the mean \pm SEM ( $n=8-10$ mice).

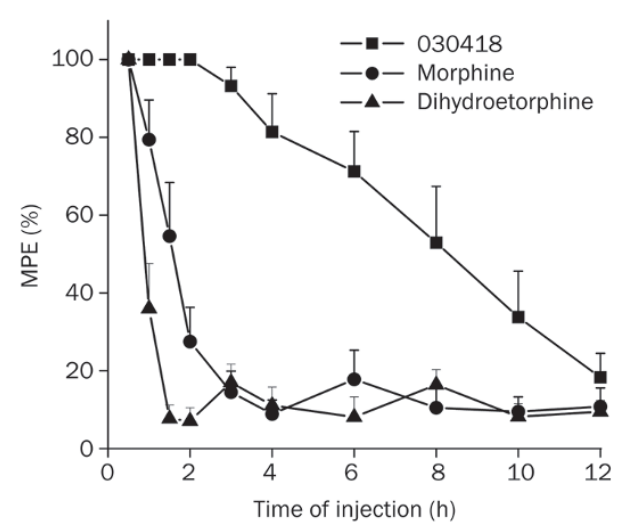

Figure 4. Time-course of the antinociceptive effects produced by the administration of $030418(6.0 \mu \mathrm{g} / \mathrm{kg} \mathrm{sc})$, dihydroetorphine $(3.0 \mu \mathrm{g} / \mathrm{kg} \mathrm{sc})$, and morphine $(10.0 \mathrm{mg} / \mathrm{kg} \mathrm{sc})$ in the mouse hot-plate test. The data are expressed as \%MPE, and each point represents the mean \pm SEM $(n=8-10$ mice).

(6.0 mg/kg, sc), DAMGO (50 ng/mouse, icv), and ( \pm )U50488 (50 $\mathrm{\mu g} /$ mouse, icv) produced a $\% \mathrm{MPE}$ of approximately $80 \%$. The antinociceptive effects of 030418 and morphine could both be blocked by the nonselective opioid receptor antagonist naloxone (Figure 5A). The selective opioid antagonists $\beta$-FNA (10 $\mu \mathrm{g} /$ mouse, icv) and nor-BNI (3.7 $\mu \mathrm{g} /$ mouse, icv) could partially block the DAMGO- and ( \pm )U50488-induced antinociception, respectively (Figure 5B and 5C). Pretreatment with the same doses of $\beta$-FNA and nor-BNI decreased the antinociceptive response to $030418(4.0 \mu \mathrm{g} / \mathrm{kg}, \mathrm{sc})$ to $26 \%$ and $50 \%$, respectively. As shown in Figure 5D, moderate doses of $030418(2.0 \mu \mathrm{g} / \mathrm{kg}, \mathrm{sc})$ and buprenorphine $(1.7 \mathrm{mg} / \mathrm{kg}$, sc) respectively produced $64 \%$ and $33 \%$ of MPE in the hotplate test. Co-administration of the ORL1 receptor antagonist J-113397 (4.0 $\mu \mathrm{g} /$ mouse, icv) enhanced the \%MPE of 030418 to $90 \%$ and that of buprenorphine to $56 \%$. In addition, these opioid antagonists administered alone did not alter the latency time in the hot-plate test because the mice that received these compounds exhibited similar levels of \% MPE relative to vehicle control mice (data not shown).

Development of 030418 tolerance and the effect of pretreatment with J-113397

The development of tolerance to 030418 and morphine across $7 \mathrm{~d}$ in the mouse hot-plate test is shown in Figure 6A. Many previous studies have used high doses of opioid drugs to induce and study tolerance ${ }^{[27,30,31]}$. As expected, repeated treatment with morphine $(30 \mathrm{mg} / \mathrm{kg}$, sc, thrice daily) induced the rapid development of analgesic tolerance. The mice started to develop tolerance on $\mathrm{d} 4$ of morphine injection and had only $45.7 \%$ MPE on $\mathrm{d} 7$. The $18 \mu \mathrm{g} / \mathrm{kg}$ dose of 030418 also produced a significant decrease in \% MPE over time. Compared with $\mathrm{d} 1,030418$ produced a significant reduction in \%MPE on d 4, 5, 6, and 7. Moreover, the decrease in antinociception observed after repeated administration of 030418 was more dramatic than that of morphine.

Subsequently, the effects of the ORL1 receptor antagonist J-113397 on analgesic tolerance to morphine and 030418 were further investigated. As mentioned above, repeated treatments with morphine led to tolerance on $\mathrm{d} 7$, and a single pretreatment with J-113397 (4.0 $\mu \mathrm{g} /$ mouse, icv) before the injection of morphine could significantly attenuate the analgesic tolerance to morphine (Figure 6B). In contrast, 030418 tolerance on $\mathrm{d} 7$ was not significantly affected by coadministration of J-113397 over the entire 8-h session (Figure 6C).

\section{Prolonged washing of 030418 from the guinea pig ileum pre- paration}

In the isolated guinea pig ileum preparation, stimulation induced by acetylcholine chloride $(1.0 \mu \mathrm{mol} / \mathrm{L})$ produces ileum muscle contraction, which can be inhibited by the action of an opioid drug added into the organ bath. The final concentrations of $0.1 \mathrm{mmol} / \mathrm{L}$ 030418, $5 \mathrm{mmol} / \mathrm{L}$ morphine, or 0.2 $\mathrm{mmol} / \mathrm{L}$ dihydroetorphine were chosen in the experiments because they could produce an approximately $80 \%$ inhibition. As shown in Figure 7, 030418, morphine and dihydro- 
A

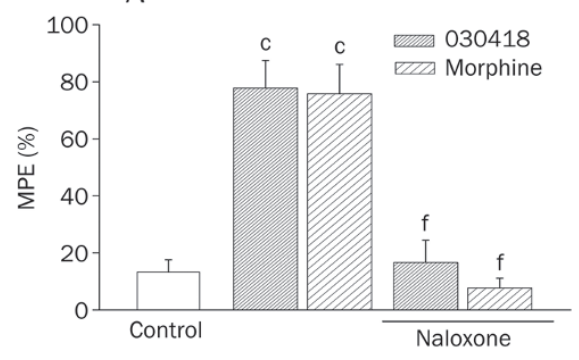

C

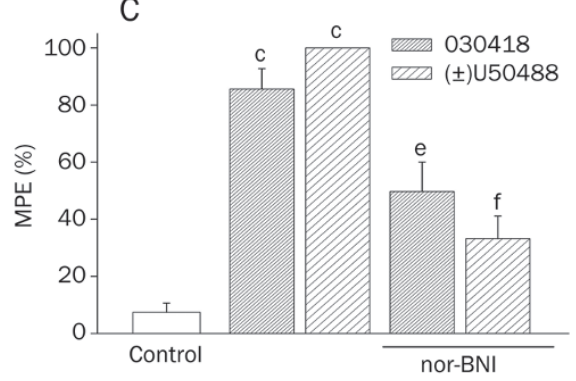

B

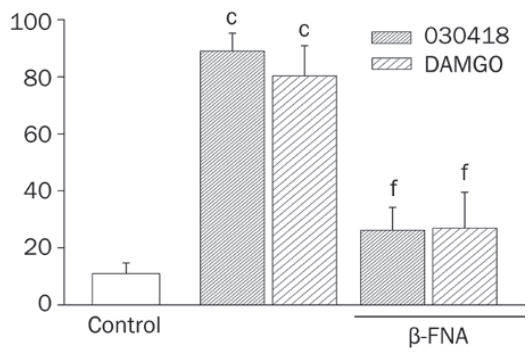

D

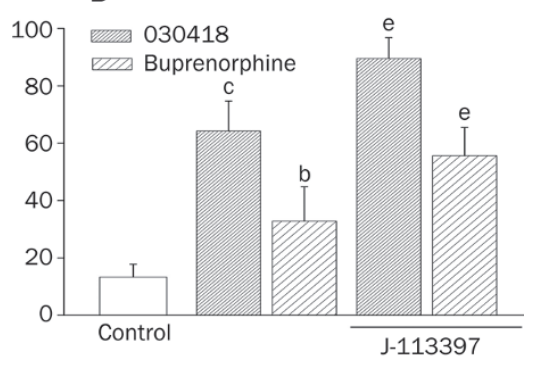

Figure 5. Effects of the nonselective opioid receptor antagonist naloxone (A), selective $\mu$-opioid receptor antagonist $\beta$-FNA (B), selective k-opioid receptor antagonist nor-BNI (C), and selective ORL1 receptor antagonist J-113397 (D) on the antinociception activity of 030418 in the mouse hot-plate

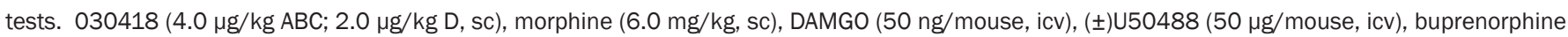
$(1.7 \mathrm{mg} / \mathrm{kg}, \mathrm{sc})$, or vehicle control were administered before testing. The mice were pretreated with naloxone $(1 \mathrm{mg} / \mathrm{kg}, \mathrm{sc}), \beta-\mathrm{FNA}(10 \mu \mathrm{m} / \mathrm{mouse}$, icv),

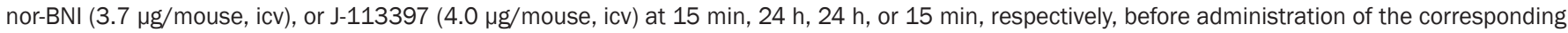
agonists. The data are expressed as \%MPE, and each point represents the mean \pm SEM $\left(n=8-10\right.$ mice). ${ }^{b} P<0.05,{ }^{c} P<0.01$ vs control; ${ }^{e} P<0.05,{ }^{f} P<0.01$ vs corresponding agonists.

A

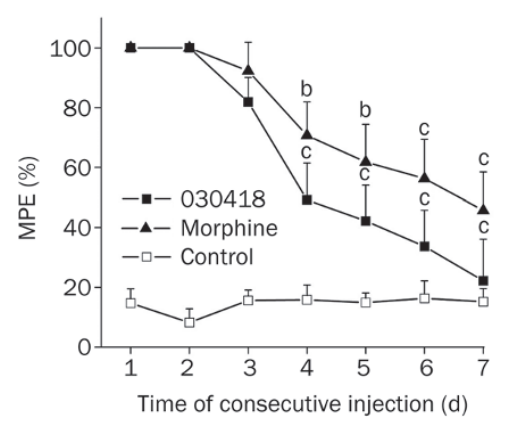

B

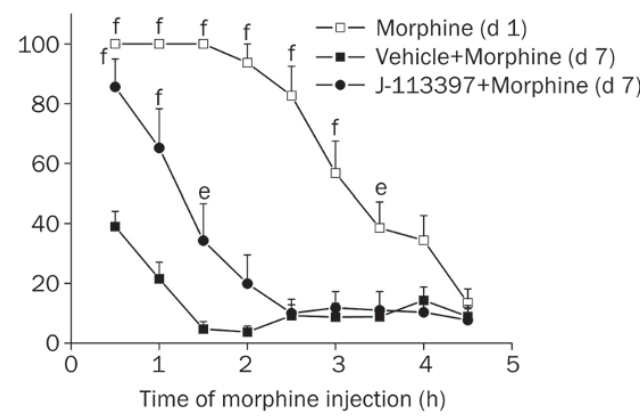

C

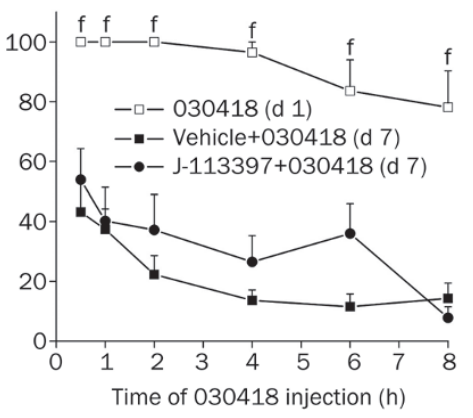

Figure 6. Effects of pretreatment with the selective ORL1 receptor antagonist J-113397 on morphine or 030418 tolerance in the mouse hot-plate test. (A) Analgesic tolerance to morphine, 030418, or vehicle control; (B) Time-course of morphine-induced antinociception without (vehicle) or with J-113397 in the tolerance model; (C) Time course of 030418-induced antinociception without (vehicle) or with J-113397 in the tolerance model. The mice repeatedly received sc injections of morphine $(30.0 \mathrm{mg} / \mathrm{kg}$, thrice daily), 030418 (18.0 $\mu \mathrm{g} / \mathrm{kg}$, once daily), or vehicle control. J-113397 (4.0 $\mu \mathrm{g} / \mathrm{mouse}$ icv) or vehicle was administered $15 \mathrm{~min}$ before the last injection of morphine or 030418 on $\mathrm{d} 7$. The data are expressed as \%MPE, and each point represents the mean \pm SEM $\left(n=8-10\right.$ mice). ${ }^{b} P<0.05,{ }^{~} P<0.01$ vs first injection on $d 1 .{ }^{e} P<0.05,{ }^{f} P<0.01$ vs vehicle+corresponding agonists at the same time on $\mathrm{d} 7$.

etorphine all significantly inhibited ileum muscle contraction stimulated by acetylcholine chloride $(1.0 \mu \mathrm{mol} / \mathrm{L})$ at time zero. During prolonged washing, the action of morphine and dihydroetorphine could be easily removed within $5 \mathrm{~min}$, which was a relatively rapid process. In comparison, the course of prolonged washing of 030418 was much slower, and the inhibitory effect of 030418 remained at $24 \%$ until $45 \mathrm{~min}$ after the attempted washout. Moreover, the time course curve of 030418 was biphasic with an initial rapid phase followed by a slower phase.

\section{Discussion}

The 6,14-bridged oripavines, which possess a $\mathrm{C}_{6}$-methoxy group part of the ring system and a long alkyl chain at the 


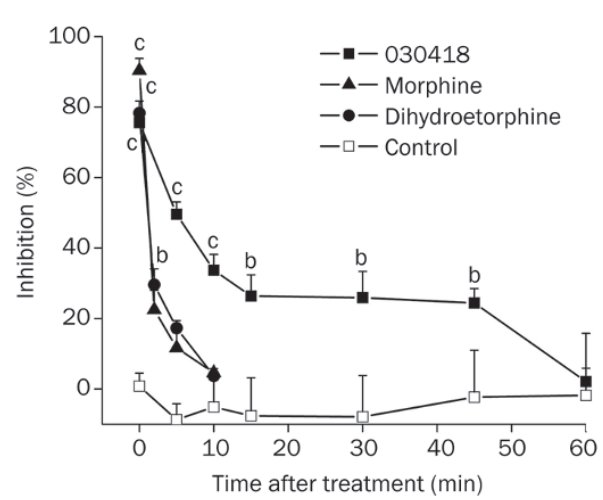

Figure 7. Time course of inhibition induced by $030418(0.1 \mathrm{mmol} / \mathrm{L})$, morphine $(5 \mathrm{mmol} / \mathrm{L})$, dihydroetorphine $(0.2 \mathrm{mmol} / \mathrm{L})$, or vehicle control on guinea pig ileum muscle contraction during prolonged washing. Ileum muscle contractions stimulated by acetylcholine chloride $(1.0 \mu \mathrm{mol} / \mathrm{L})$ were recorded as the sample responses. The data are expressed as $\%$ inhibition, and each point represents the mean \pm SEM ( $n=3-4$ samples). ${ }^{\mathrm{b}} P<0.05,{ }^{\mathrm{c}} P<0.01$ vs control at the same time.

$C_{7}$ substituent, have been reported to have high affinity to opioid receptors ${ }^{[6]}$. As expected, the receptor binding assay revealed that 030418 , a novel 6,14-bridged oripavine compound, displayed nonselective binding affinities to the $\mu-, \mathrm{K}-$, and $\delta$-opioid receptors and the ORL1 receptor with $K_{\mathrm{i}}$ values in the nanomolar range, as did thienorphine. Moreover, our observation that thienorphine highly bound to the $\mu-, \mathrm{k}-$, and $\delta$-opioid receptors is in accord with previous reports ${ }^{[15,16]}$.

Consistent with $\mathrm{Li}$ et $a l^{[16]}$, thienorphine exhibited partial agonist activity at the $\mathrm{k}$-opioid receptor and at the $\mu$-opioid receptor (to a lesser extent) but not at the $\delta$-opioid receptor in vitro. In contrast, 030418 , which has a methyl group at the $\mathrm{N}_{17}$ substituent, was more efficacious in stimulating $\left[{ }^{35} \mathrm{~S}\right] \mathrm{GTP} \gamma \mathrm{S}$ binding at the $\mu-, \mathrm{K}-$, and $\delta$-opioid receptors and the ORL1 receptor than its parent congener, thienorphine. This compound was also equally as efficacious as dihydroetorphine at all subtypes of the receptors except at the ORL1 receptor. Several structure-activity relationship (SAR) studies have shown that the 6,14-bridged oripavines with a cyclopropylmethyl group at $\mathrm{N}_{17}$, such as diprenorphine, buprenorphine, and naltrexone, might possess some morphine-antagonist characteristics. Replacing this group with a methyl group has been found to greatly increase the efficacy of compounds, particularly at the $\mu$ - and $\mathrm{k}$-opioid receptors ${ }^{[11,12]}$. We also considered that the mixed ORL1/ $\mu$-opioid receptor activity of 030418 may have an attractive profile for the treatment of pain and addiction, similar to SR16435 and buprenorphine ${ }^{[32,33]}$. However, explaining the nonselective agonism of 030418 at opioid receptors will be difficult, and further studies are required to provide insights into the SAR of 030418 and the 6,14-bridged oripavine scaffold.

In the mouse tail-flick test and hot-plate test, the antinociceptive potency of 030418 was similar to that of the typical full agonist dihydroetorphine. Moreover, the $\mathrm{ED}_{50}$ value of 030418 was in the microgram range and was calculated as approximately 1100-1500 times that of the standard morphine hydrochloride. Experimental data regarding the potency of dihydroetorphine and morphine were consistent with those of Aceto $e t a l^{[34]}$. In addition, 030418 had more potent and powerful antinociceptive effects in vivo than its parent compound thienorphine, which has previously been demonstrated to be a partial opioid agonist, with an $\mathrm{ED}_{50}$ value in the milligram range in the mouse antinociceptive tests ${ }^{[15]}$. Compared with morphine, 030418 shows a rather long-lasting duration of the antinociceptive effect in the hot-plate test, which is similar to thienorphine. This similarity could occur because 030418 and thienorphine may have tight lipophilic interactions with the binding pocket of opioid receptors given the high liposolubility of the $C_{7}$ substituent. This feature may lead to the persistent occupation of the opioid receptors by 030418. Several early reports have also demonstrated that 6,14-bridged oripavine compounds have very powerful binding interactions with opioid receptors and thus slow receptor kinetics, which causes a long-lasting effect ${ }^{[35-37]}$.

Using pharmacological blockade in the hot-plate tests, the antinociception mediated by 030418 could be fully reversed by systemic administration of the classic opioid receptor antagonist naloxone, suggesting that the antinociceptive effect of 030418 , similar to morphine, is likely related to the opioid receptor system. In addition, icv pretreatment with either $\beta$-FNA ( $\mu$-opioid receptor antagonist) or nor-BNI ( $\kappa$-opioid receptor antagonist) was found to decrease 030418-induced antinociception. These results indicate that the activation of supraspinal $\mu$ - and $\mathrm{k}$-opioid receptors appears to be involved in the antinociceptive effect of 030418 . The $\mu$-opioid receptor is generally considered to represent the major molecular gate for opioid analgesia, and the activation of the k-opioid receptor also evokes an analgesic action ${ }^{[38]}$. More interestingly, icv pretreatment with J-113397 (ORL1 receptor antagonist) could enhance antinociception induced by a moderate dose of 030418. In summary, the experimental results demonstrate that systemic administration of 030418 can simultaneously activate the $\mu$ - and $\mathrm{k}$-opioid receptor and the ORL-1 receptor in vivo.

Although 030418 showed remarkable antinociceptive effects, high doses of this compound unfortunately produced significant and rapid development of analgesic tolerance. In chronically administered animal models, 030418 produced a $78 \%$ decrease in \%MPE on d 7 relative to $\mathrm{d} 1$; in comparison, morphine produced a $54 \%$ decrease in \%MPE. Although repeated administration of opioid agonists unavoidably produces analgesic tolerance associated with adaptive changes on opioid receptors and complex molecular events in cellular signaling pathways ${ }^{[39]}$, our observation of the dramatic development of tolerance to 030418, which activates both the ORL1 and the $\mu$-opioid receptors, seems contradictory to earlier reports. These studies have hypothesized that a compound that contains both $\mu$-opioid receptor and ORL1 receptor agonist activities has reduced tolerance development ${ }^{[32,33]}$. Thus, we next investigated the effect of pretreatment with the selective ORL1 antagonist J-113397 on 030418 tolerance. The experimental 
results suggested that pharmacological blockade with J-113397 significantly prevented analgesic tolerance to morphine on $\mathrm{d} 7$, which confirms earlier findings ${ }^{[30,31]}$. In contrast, pretreatment with J-113397 could not effectively alter the development of tolerance to 030418. These findings highlight the complicated relationship between ORL1 receptor activation and $\mu$-opioid receptor mediated tolerance. Therefore, additional studies are necessary to explain the issue.

Previous $\left.{ }^{35} \mathrm{~S}\right] \mathrm{GTP} \gamma \mathrm{S}$ assays have revealed the high efficacy of 030418 at $\mu$ - and $\kappa$-opioid receptors; therefore, the inhibition by 030418 on muscle contraction in the guinea pig ileum (a tissue with enriched populations of functional $\mu$ - and $\kappa-$-opioid receptors) seen in this study may have been primarily mediated through opioid receptor activity. Notably, the action of 030418 could be removed (with difficulty, compared to morphine and dihydroetorphine) by repeated, prolonged washing. This finding, taken together with the observation that 030418 had high binding affinity to opioid receptors, clearly indicates that 030418 has slow receptor dissociation kinetics. Considering that the only difference between 030418 and dihydroetorphine exists in the $C_{7}$ substituent structure (Figure 1 ), the persistent binding affinity of 030418 to the opioid receptors may result from the high hydrophobicity caused by the structure of the $\mathrm{C}_{7}$-thiophene group. Similar examples of slow receptor dissociations of buprenorphine and BU74 have been observed and have been explained by powerful lipophilic binding interactions with the opioid receptors ${ }^{[37,40]}$. The pharmacological property of slow receptor dissociation kinetics may account for the long duration of the agonist effect of 030418 in vivo. Additionally, the persistent occupation of the opioid receptors, particularly the $\mu$-opioid receptors, can easily lead to the development of tolerance to 030418 by either receptor phosphorylation or a combination of receptor phosphorylation and desensitization. Woolf and Linderman ${ }^{[41]}$ have believed that the ligand receptor dissociation rate constant and the conformational selectivity factor, which roughly corresponds to a drug's efficacy, positively conspire to regulate receptor phosphorylation.

In conclusion, the present study demonstrates that 030418 , a 6,14-bridged oripavine compound, is a nonselective, highaffinity, and full opioid receptor agonist in vitro. This compound has highly potent and long-lasting antinociceptive effects, and tolerance to 030418 rapidly develops in vivo. The pharmacological properties of 030418 closely correlate with a high activity of the methyl group at the $\mathrm{N}_{17}$ position and high hydrophobicity of the $\mathrm{C}_{7}$-thiophene group in the 030418 chemical structure. The results of this study indicate that 030418 may be a candidate for development in the management of acute pain or as a 'universal' opioid ligand to be used as a pharmacological tool. Although more efforts are needed to discover the possible mechanisms of the unique effects of 030418, the current findings help to further understand the SAR of 6,14-bridged oripavines and provide insights into the design of ideal opioid drugs.

\section{Acknowledgements}

This work was supported by the National High Technology Research and Development Program of China (No 2005AA233040) and the National S\&T Major Project of Original New Drug Research of China (№ 2009ZXJ09004-079). We acknowledge Dr Bo-hua ZHONG and his group for supplying samples of 030418 and thienorphine for these experiments. We also thank Dr Zheng YONG and Dr Yan GAO for excellent expert technical assistance.

\section{Author contribution}

Ze-hui GONG and Ling-di YAN designed the research; Quan WEN and Yu-lei LI performed the research; Quan WEN and Gang YU analyzed the data; and Quan WEN wrote the paper.

\section{References}

1 Cherny NJ, Chang V, Frager G, Ingham JM, Tiseo PJ, Popp B, et al. Opioid pharmacotherapy in the management of cancer pain: a survey of strategies used by pain physicians for the selection of analgesic drugs and routes of administration. Cancer 1995; 76: 1283-93.

2 Koob GF, Le Moal M. Drug abuse: hedonic homeostatic dysregulation. Science 1997; 278: 52-8.

3 Berger AC, Whistler JL. How to design an opioid drug that causes reduced tolerance and dependence. Ann Neurol 2010; 67: 559-69.

4 Bentley KW, Hardy DG. Novel analgesics and molecular rearrangements in the morphine-thebaine group. I. Ketones derived from 6,14-endo-ethenotetrahydrothebaine. J Am Chem Soc 1967; 89: 3267-73.

5 Bentley KW, Hardy DG. Novel analgesics and molecular rearrangements in the morphine-thebaine group. III. Alcohols of the 6,14-endo-ethenotetrahydrooripavine series and derived analogs of N-allylnormorphine and -norcodeine. J Am Chem Soc 1967; 89: 3281-92.

6 Lewis JW, Husbands SM. The orvinols and related opioids - high affinity ligands with diverse efficacy profiles. Curr Pharm Des 2004; 10: 717-32.

7 Cowan A, Lewis JW, MacFarlane IR. Agonist and antagonist properties of buprenorphine, a new antinociceptive agent. Br J Pharmacol 1977; 60: $537-45$.

8 Mello NK, Mendelson JH, Lukas SE, Gastfriend DR, Teoh SK, Holman BL. Buprenorphine treatment of opiate and cocaine abuse: clinical and preclinical studies. Harv Rev Psychiatry 1993; 1: 168-83.

9 Picard PR, Tramer MR, McQuay HJ, Moore RA. Analgesic efficacy of peripheral opioids (all except intra-articular): a qualitative systematic review of randomised controlled trials. Pain 1997; 72: 309-18.

10 Barnett PG, Rodgers JH, Bloch DA. A metaanalysis comparing buprenorphine to methadone for treatment of opiate dependence. Addiction 2001; 96: 683-90.

11 Park HS, Lee HY, Kim YH, Park JK, Zvartau EE, Lee H. A highly selective kappa-opioid receptor agonist with low addictive potential and dependence liability. Bioorg Med Chem Lett 2006; 16: 3609-13.

12 Rennison D, Neal AP, Cami-Kobeci G, Aceto MD, Martinez-Bermejo F, Lewis JW, et al. Cinnamoyl derivatives of $7 \alpha$-aminomethyl-6,14-endoethanotetrahydrothebaine and $7 \alpha$-aminomethyl-6,14-endoethanotetrahydrooripavine and related opioid ligands. J Med Chem 2007; 50: 5176-82.

13 Liu CH, Liu H, Han XY, Wu B, Zhong BH, Gong ZH. Synthesis and characterization of thienorphine and its glucuronide conjugate. Synth Commun 2005; 35: 701-10. 
14 Zhao WL, Gong ZH, Liang JH. A new buprenorphine analogy, thienorphine, inhibits morphine-induced behavioral sensitization in mice. Acta Pharmacol Sin 2004; 25: 1413-8.

15 Yu G, Yue YJ, Cui MX, Gong ZH. Thienorphine is a potent long-acting partial opioid agonist: a comparative study with buprenorphine. J Pharmacol Exp Ther 2006; 318: 282-7.

16 Li JX, Becker GL, Traynor JR, Gong ZH, France CP. Thienorphine: receptor binding and behavioral effects in rhesus monkeys. J Pharmacol Exp Ther 2006; 321: 227-36.

17 Yu G, Liu YS, Yan LD, Wen Q, Gong ZH. Structure-activity relationships analysis of thienorphine and its derivatives. Yao Xue Xue Bao 2009; 44: $726-30$.

18 Loew GH, Berkowitz DS. Intramolecular hydrogen bonding and conformational studies of bridged thebaine and oripavine opiate narcotic agonists and antagonists. J Med Chem 1979; 22: 603-7.

19 Sebastian A, Bidlack JM, Jiang Q, Deecher D, Teitler M, Glick SD, et al. 14 beta-[(p-nitrocinnamoyl)amino]morphinones, 14 beta-[( $p$-nitrocinnamoyl)amino]-7,8-dihydro-morphinones, and their codeinone analogues: synthesis and receptor activity. J Med Chem 1993; 36 : 3154-60.

20 Zhu J, Luo LY, Chen C, Liu-Chen LY. Activation of the cloned human kappa-opioid receptor by agonists enhances $\left[{ }^{35} \mathrm{~S}\right] \mathrm{GTPgammaS}$ binding to membranes: determination of potencies and efficacies of ligands. J Pharmacol Exp Ther 1997; 282: 676-68.

21 Bradford MM. A rapid and sensitive method for the quantitation of microgram quantities of protein utilizing the principle of protein-dye binding. Anal Biochem 1976; 72: 248-54.

22 D'Amour FE, Smith DL. A method for determining loss of pain sensation. J Pharmacol Exp Ther 1941; 72: 74-9.

23 Eddy NB, Leimbach D. Synthetic analgesics. II. Dithienylbutenyl- and dithienylbutylamines. J Pharmacol Exp Ther 1953; 107: 385-93.

24 Horan P, Taylor J, Yamamura HI, Porreca F. Extremely long-lasting antagonistic actions of nor-binaltorphimine (nor-BNI) in the mouse tail-flick test. J Pharmacol Exp Ther 1992; 260: 1237-43.

25 Craft RM, Henley SR, Haaseth RC, Hruby VJ, Porreca F. Opioid antinociception in a rat model of visceral pain: systemic versus local drug administration. J Pharmacol Exp Ther 1995; 275: 1535-42.

26 Lutfy K, Eitan S, Bryant CD, Yang YC, Saliminejad N, Walwyn W, et al. Buprenorphine-induced antinociception is mediated by mu-opioid receptors and compromised by concomitant activation of opioid receptor-like receptors. J Neurosci 2003; 23: 10331-7.

27 Wu N, Lu XQ, Yan HT, Su RB, Wang JF, Liu Y, et al. Aquaporin 4 deficiency modulates morphine pharmacological actions. Neurosci Lett 2008; 448: 221-5.
28 Paton WD, Vizi ES. The inhibitory action of noradrenaline and adrenaline on acetylcholine output by guinea-pig ileum longitudinal muscle strip. Br J Pharmacol 1969; 35: 10-28.

29 Bliss Cl. Statistics in biology. New York: McGraw-Hill Book Company; 1967.

30 Ueda H, Inoue M, Takeshima H, Iwasawa Y. Enhanced spinal nociceptin receptor expression develops morphine tolerance and dependence. J Neurosci 2000; 20: 7640-7.

31 Chung S, Pohl S, Zeng J, Civelli O, Reinscheid RK. Endogenous orphanin $\mathrm{FQ} /$ nociceptin is involved in the development of morphine tolerance. J Pharmacol Exp Ther 2006; 318: 262-7.

32 Khroyan TV, Zaveri NT, Polgar WE, Orduna J, Olsen C, Jiang F, et al. SR 16435 [1-(1-(bicyclo[3.3.1]nonan-9-yl)piperidin-4-yl)indolin-2-one], a novel mixed nociceptin/orphanin FQ/mu-opioid receptor partial agonist: analgesic and rewarding properties in mice. J Pharmacol Exp Ther 2007; 320: 934-43.

33 Spagnolo B, Calo G, Polgar WE, Jiang F, Olsen CM, Berzetei-Gurske I, et al. Activities of mixed NOP and mu-opioid receptor ligands. $\mathrm{Br} J$ Pharmacol 2008; 153: 609-19.

34 Aceto MD, Harris LS, Bowman ER. Etorphines: mu-opioid receptorselective antinociception and low physical dependence capacity. Eur J Pharmacol 1997; 338: 215-23.

35 Boas RA, Villiger JW. Clinical actions of fentanyl and buprenorphine. The significance of receptor binding. Br J Anaesth 1985; 57: 192-6.

36 Neilan CL, Husbands SM, Breeden S, Ko MC, Aceto MD, Lewis JW, et al. Characterization of the complex morphinan derivative BU72 as a high efficacy, long-lasting mu-opioid receptor agonist. Eur J Pharmacol 2004; 499: 107-16.

37 Husbands SM, Neilan CL, Broadbear J, Grundt P, Breeden S, Aceto $\mathrm{MD}$, et al. BU74, a complex oripavine derivative with potent kappa opioid receptor agonism and delayed opioid antagonism. Eur J Pharmacol 2005; 509: 117-25.

38 Pasternak GW. Pharmacological mechanisms of opioid analgesics. Clin Neuropharmacol 1993; 16: 1-18.

39 Kieffer BL, Evans CJ. Opioid tolerance - in search of the holy grail. Cell 2002; 108: 587-90.

40 Hambrook JM, Rance MJ. The interaction of buprenorphine with the opiate receptor: lipophilicity as a determining factor in drug-receptor kinetics. In: Kosterlitz HW, editor. Opiates and endogenous opioid peptides. Amsterdam: Elsevier; 1976. p 295-301.

41 Woolf PJ, Linderman JJ. Untangling ligand induced activation and desensitization of G-protein coupled receptors. Biophys J 2003; 84: 3-13. 